Winter 2009

\title{
Navigating the Turbulent Waters Connecting the World Trade Organization and Corporate Social Responsibility
}

\author{
Gustavo Ferreira Ribeiro \\ Indiana University Maurer School of Law
}

Follow this and additional works at: https://www.repository.law.indiana.edu/ijgls

Part of the Business Organizations Law Commons, International Law Commons, International Trade Law Commons, and the Law and Politics Commons

\section{Recommended Citation}

Ribeiro, Gustavo Ferreira (2009) "Navigating the Turbulent Waters Connecting the World Trade Organization and Corporate Social Responsibility," Indiana Journal of Global Legal Studies: Vol. 16 : Iss. 1 , Article 9.

Available at: https://www.repository.law.indiana.edu/ijgls/vol16/iss1/9

This Symposium is brought to you for free and open access by the Law School Journals at Digital Repository @ Maurer Law. It has been accepted for inclusion in Indiana Journal of Global Legal Studies by an authorized editor of Digital Repository @ Maurer Law. For more information, please contact rvaughan@indiana.edu.

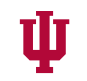

JEROME HALL LAW LIBRARY

INDIANA UNIVERSITY

Maurer School of Law
Bloomington 


\title{
Navigating the Turbulent Waters Connecting the World Trade Organization and Corporate Social Responsibility
}

\author{
Gustavo Ferreira Ribeiro*
}

\begin{abstract}
This paper uses the metaphor of a fisherman's journey into the World Trade Organization (WTO) and Corporate Social Responsibility (CSR) "seas" to explore the relationship between them. It is intended to provide the reader with a basic understanding of this relationship. An argument can be made that the WTO and CSR waters are not connected at all: the $W T O$ is an intergovernmental organization regulating rights and duties of its members (mainly states), while CSR concerns primarily non-governmental initiatives dealing with corporate behavior, such as voluntary codes of conduct and certification processes involving social and environmental standards. However, this paper explores the straits potentially connecting the seas and the sea creatures that represent the relevant jurisprudence informing the debate.
\end{abstract}

\section{INTRODUCTION}

A fisherman has been seen navigating two different seas for many years: the World Trade Organization (WTO) and Corporate Social Responsibility (CSR). He built two different vessels because he could not figure out a way to cross from one sea to the other. Finally, he envisioned a strait that could provide the necessary

*S.J.D. Candidate and Capes (Brazilian Education Agency)/Fulbright Grantee, Indiana University Maurer School of Law - Bloomington. Email: gribeiro@umail.iu.edu. I would like to thank Professor Christiana Ochoa, Professor Hannah Buxbaum, and Jonathan Henriques for their comments. Omissions and errors are exclusively mine. An earlier version of this paper was presented at the Indiana Journal of Global Legal Studies Symposium on Operationalizing Global Governance, Bloomington, Indiana, March 19-21, 2008, under the title "The Role (or Hole) of the World Trade Organization Towards Corporate Social Responsibility."

Indiana Journal of Global Legal Studies Vol. $16 \# 1$ (Winter 2009)

OIndiana University Maurer School of Law - Bloomington 
connection. For decades, the myth of monsters along the way had terrorized those who dared into the strait. He climbed aloft nevertheless.

He could see the strait and thought that, in due course, he would be able to feed on the many species said to be found in those waters-tuna, turtles, shrimp, sardines, and salmon. He began the journey looking for lights from the beacon on the other side. Some said that his quest would be endless, and his vessel would go down.

If you can immediately grasp the sense of the story above, you may find another port as your best departure point. ${ }^{1}$ If you are still wondering what this story is all about, you are in the right place. This is an introductory article for those interested in the debate linking the WTO with CSR. If this is your first journey into this topic, this article is your compass. Welcome to the vessel. Prepare to meet sea creatures forming the relevant jurisprudence and to seek the lights of the beacon. ${ }^{2}$

Your journey will be divided into five short trips. The first two constitute overviews of the WTO and CSR. The third and fourth parts steer the vessel to the possible confluence of the topics and the relevant law involved. Finally, the fifth part presents reactions to recent accounts on the topic.

\section{The World Trade Organization}

\section{A. Background}

We begin in the sea of the WTO. While embarking on this journey, it is important to note that the WTO is an intergovernmental organization created at the end of the Uruguay Round (1986-1993) after almost five decades of operation of the General Agreement on Tariffs and Trade (GATT 1947). ${ }^{3}$ The signatories of

1. Three recently published papers addressing World Trade Organization (WTO) and Corporate Social Responsibility (CSR) issues provide an excellent point of departure. See generally Susan A. A a ronson, A Match Made in the Corporate and Public Interest: Marrying Voluntary CSR Initiatives and the WTO, 41 J. WORLD TRADE 629 (2007); Steven Bernstein \& Erin Hannah, Non-State Global Standard Setting and the WTO: Legitimacy and the Need for Regulatory Space, 11 J. INT'L ECON. L. 575 (2008); Caroline E. Foster, Public Opinion and the Interpretation of the World Trade Organization's Agreement on Sanitary and Phytosanitary Measures, 11 J. INT'L ECON L. 427 (2008). I will react to these recent accounts in Part V.

2. The closest metaphor I could find comparing the WTO to fishermen is Michael Lennard, Navigating by the Stars: Interpreting the WTO Agreements, 5 J. INT'L ECON. L. 17, 17 (2002) (comparing the process of interpretation of WTO agreements with the first voyages of early navigators and suggesting that the WTO institutions must look for reliable reference points in the known legal "cosmology").

3. A "round" refers to a period in which the Contracting Parties of the General Agreement on Tariffs and Trade (GATT 1947) convene to agree (or disagree) on some issue related to trade. The 
the GATT 1947 are referred to as Contracting Parties, while the WTO signatories are referred to as members. ${ }^{4}$

The GATT 1947 is one of the chapters of the so-called "Havana Charter." The charter was meant to establish an intergovernmental organization, the International Trade Organization (ITO), which, for many reasons, never came into existence. ${ }^{5}$ Instead, the GATT 1947 was applied provisionally, and in the view of some commentators, it became a de facto international organization after decades of operation.

The GATT 1947 is said to be part of the Bretton Woods system, which is comprised of the International Monetary Fund (IMF) and the World Bank. The WTO is not part of the United Nations system in any formal way. However, it does intersect with the United Nations through institutional cooperation, joint studies, and other activities among the WTO and U.N.-related bodies. As of July 2008, the WTO had 153 members. ${ }^{6}$

\section{B. Trade Barriers}

Overall, the WTO aims at trade liberalization through the elimination of trade barriers among its members. The WTO relies on the premise, largely supported by economic theory, that trade liberalization generates economic growth and better standards of living worldwide. ${ }^{7}$ Trade barriers exist for many reasons, some of which are legitimate and genuine. The problem is that trade barriers may

GATT 1947 had eight rounds. The WTO also has this dynamic, and the WTO is currently in the Doha Development Round (DDR), which began in September 2001.

4. I use "members" to refer only to WTO members. Whenever I refer to any other membership, I will precede the term with the corresponding organization (e.g., U.N. members).

5. For those interested in the GATT 1947 history and explanations of the political context that led to the failure of the ITO, see John H. Jackson, THe World Trading System: Law and Policy of International Economic Relations 31-43 (2d ed. 1997). See also Douglas A. Irwin ET AL., THE Genesis of THE GATT 98 (2008).

6. For the membership list, see Members and Observers, http://www.wto.org/english/thewto_e/ whatis_e/tif_e/org6_e.htm (last visited Nov. 5, 2008).

7. In an even broader perspective, it is a project about peace and stability that has been associated with a quotation attributed to Frederic Bastiat: "[i]f goods don't cross borders, armies will." As Dean Russell explained, that exact quotation does not appear in any of Bastiat's writings, but the idea was clearly endorsed by Bastiat in several passages. See DEAN Russell, Frederic Bastiat: IDEAS AND INFLUENCE 44 (1965). This paper does not discuss criticisms of that economic assumption. It merely reproduces the preamble of the GATT 1947 that recognizes that "trade and economic endeavour should be conducted with a view to raising standards of living, ensuring full employment and a large and steadily growing volume of real income." See General Agreement on Tariffs and Trade, pmbl., Jan. I, 1948, T.I.A.S. No. 1700 [hereinafter GATT 1947]. 
also simply serve protectionist purposes. This concern highlights the central purpose of the WTO, which is to distinguish, by agreed-upon rules, situations of legitimate discriminatory behavior from situations of illegitimate protectionism.

Trade barriers are implemented in many ways and are often part of legislation, resolutions, or decrees that emanate from governmental bodies. Trade barriers a re inserted in trade measures which are adopted by governments. A traditional trade barrier is a tariff (a tax on the importation of a good), but currently, many other non-tariff barriers (NTB) exist.

The WTO has at least three main features in place to deal with trade barriers. The first is a set of rules or treaties referred to as the "covered agreements." These norms embrace the multilateral rules establishing the principles of nondiscrimination central to WTO membership. Two of the central clauses are the Most Favored Nation (MFN) and the National Treatment (NT) clauses, which are found in the GATT 1994 Articles I and III, respectively. ${ }^{9}$ Second, the WTO is also a negotiating forum where members, through their diplomats, meet to negotiate for, among other things, enhanced market access. Finally, the WTO also provides a "tribunal" for member-to-member disputes by establishing a two-level proceeding that operates as follows: first, disputes are analyzed by a panel of experts; second, the panel's findings may be appealed to the Appellate Body (AB) of the WTO. The idea of two-tier proceedings (panels and the AB) is analogous to levels of jurisdiction in domestic courts. The Dispute Settlement Body (DSB) is the administrative organ that selects disputes upon request and monitors the pro-

8. The Marrakesh Protocol is merely the Final Act signed by the founding members of the WTO; it is like a cover note. Attached to the Final Act are the Agreement Establishing the WTO (the WTO Agreement), an umbrella agreement, and four annexes providing substantial rules on trade. The list of the "covered agreements" is found in Annex 2, Appendix 1. Annex 1A contains the Multilateral Agreements on Trade in Goods (such as the GATT 1994, which is read together with the GATT 1947, the Sanitary and Phytosanitary Measures (SPS), and the Technical Barriers to Trade, among others); Annex 1B contains the General Agreement on Trade in Services (GATS); Annex 1C contains the Trade-Related Aspects of Intellectual Property Rights (TRIPS); Annex 2 contains the Dispute Settlement Understanding (DSU); Annex 3 contains the Trade Policy Review Mechanism (TPRM); and Annex 4 contains the Plurilateral Trade Agreements (such as the Annex 4(b): Government Procurement Agreement (GPA)). See General Agreement on Tariffs and Trade, Apr. 15, 1994, 33 I.L.M. 1125 [hereinafter GATT 1994].

9. In trade in goods, the National Treatment (NT) clause obliges members to accord treatment no less favorable than that accorded to "like products" of national origin. The clause aims to prevent domestic policies, such as taxation and regulatory practices that nullify the benefits obtained in relation to customs. The Most Favored Nation (MFN) clause is a basic element of non-discrimination among the parties. The clause obliges a member to treat other members in a non-discriminatory way. 
ceedings. ${ }^{10}$ The WTO expects that members will abide by the decisions, and in the event of non-compliance, the WTO may authorize trade retaliation.

\section{Relevant Covered Agreements: The GATT 1994, the TBT, the SPS, and the GPA}

Among the WTO covered agreements, the following four are of special relevance to this article's journey: the GATT 1994, the Agreement on Technical Barriers to Trade(TBT), the Agreement on the Application of Sanitary and Phytosanitary (SPS) Measures, and the Governmental Procurement Agreement (GPA).

The GATT 1994 is the cornerstone of the multilateral trade system. Essentially, it incorporates the text of the GATT 1947 with necessary modifications. For instance, the references to "Contracting Parties" in the provisions of the GATT 1947 are read as "members" in the GATT 1994."

The SPS and TBT have their origin in the Standards Code (1979). As Gabrielle Marceau and Joel Trachtman explain, after the Kennedy Round (1964-1967), the Contracting Parties expressed their concern that the "increasing multiplicity of standards was seen as a potential barrier to trade and [the Contracting Parties] pointed towards a need to consider harmonization of standards." 2 The concern was twofold. First, if a standard exists, exchange is facilitated because incompatibility of products can be reduced. In addition, standards can be harmonized by many countries, which further facilitate trade. Second, the Contracting Parties called attention to the fact that anything to be agreed upon should not interfere with the "responsibility of governments for safety, health and welfare of their people or for the protection of the environment in which they live." ${ }^{13}$ With those two sets of concerns in mind, forty-three Contracting Parties signed the Standards Code in the Tokyo Round (1973-1979). The Standards Code covered mandatory and voluntary technical specifications, mandatory technical regulations, and voluntary standards for industrial and agricultural goods. In the 1980s, nonetheless, a consensus emerged that the Standards Code did not avoid protectionism related to the proliferation of

10. To clarify, placing tribunal in quotation marks simply indicates that there has been debate regarding the legal nature of WTO dispute settlement. A commentator refers to it as a mechanism of "judicial supervision" rather than "dispute settlement," though this point is of less consequence with respect to this paper's topic. See Yuji Iwasawa, WTO Dispute Settlement as Judicial Supervision, 5 J. INT'L. ECON. L. 287, 292-93 (2002).

11. GATT 1994 , supra note 8 , at 1155 .

12. Gabrielle Marceau \& Joel P. Trachtman, The Technical Barriers to Trade Agreement, the Sanitary and Phytosanitary Measures Agreement, and the General Agreement on Tariffs and Trade, $36 \mathrm{~J}$. WORLD TRADE 814, 814 (2002).

13. Id. 
technical regulations. Furthermore, it appears that technical specificities on agricultural issues required the Contracting Parties to establish different disciplines for agriculture and general standards. Thus, during the Uruguay Round, the Standards Code served as the basis for two new agreements: the TBT and the SPS. ${ }^{14}$

The GPA, on the other hand, deals with procurement of products and services by governments (and their respective agencies). ${ }^{15}$ Procurement generally accounts for an important share of government expenditures, and many governments impose a requirement that their suppliers be domestic corporations. ${ }^{16}$ As with the TBT and SPS, the roots of the GPA preceded the establishment of the WTO. Annet Blank and Gabrielle Marceau, in fact, acknowledge that attempts to negotiate an agreement of procurement began in the 1940s. ${ }^{17}$ However, government procurement provisions were explicitly excluded from the GATT 1947 framework, and an agreement was possible only during the Tokyo Round. ${ }^{18}$ With the establishment of the WTO, a revised GPA was proposed and entered into force in 1996. Currently, it is in force for thirty-nine members. ${ }^{19}$

14. Id. at $814-15$.

15. The creation of an agreement on procurement is aimed at enhancing transparency and reducing governmental discrimination against foreign suppliers (through application of a national treatment clause).

16. See Christopher R. Yukins \& Steven L. Schooner, Incrementalism: Eroding the Impediments to a Global Public Procurement Market, 38 GEo. J. INT'L L. 529, 533, 535 (2007) (analyzing the size of the procurement market and how a variety of international organizations, such as the WTO, can work to promote free trade on government procurement).

17. Annet Blank \& Gabrielle Marceau, A History of Multilateral Negotiations on Procurement: From ITO to WTO, in Law and Policy in Public Purchasing: The WTO Agreement on Government Procurement 31, 32-36 (Bernard M. Hoekman \& Petros C. Mavroidis eds., 1997).

18. During the ITO negotiations, it seems that the delegates were at odds about the meaning of government procurement, state trading, and government contracts awards. In the end, government procurement was explicitly excluded from the obligation of National Treatment (Article III of GATT), and the state-trading clause (Article XVII of GATT) contained only a soft obligation of "fair and equitable treatment" concerning government procurement. Blank and Marceau, nevertheless, argue that the MFN clause could potentially apply to government procurement. Id. at 32-37. They also comment that, to a very large extent, the logic and wording of the 1979 GPA draws on the draft developed by the Organization for Economic Cooperation and Development during the 1960s and 1970s. Id. at 37-41.

19. For an updared list of the signatories of the GPA, see WTO-Government Procurement, http://www.wto.org/english/tratop_e/gproc_e/memobs_e.htm (last visited Oct. 4, 2008). As mentioned, while the Agreement on the Application of Sanitary and Phytosanitary Measures (SPS) and the TBT are an integral part of the WTO Agreement and binding on all members, the GPA is a multilateral treaty; the GPA binds only members who expressly adopt it, and members can opt in or out. In the literature, TBT and SPS are described as part of a "single undertaking" of the WTO, while the GPA is a "plurilateral" agreement. 


\section{Recent Trends}

Thirteen years have passed since the WTO was established. Three major trends are significant to the discussion in this article. First, the establishment of the WTO resulted in a more comprehensive range of topics covered by the organization. As such, the WTO became more visible to civil society and often a target of anti-globalization activists. A classic example is the Seattle protests in 1999, where non-governmental organizations (NGOs) and civil society groups unleashed harsh criticisms of the WTO and blamed the organization for the detrimental effects of globalization.

Second, because of the high-profile trade interests involved (and, one could say, for the benefits provided by its litigation proceedings), the DSB has been frequently called upon not only by developed nations, but also by developing and, though less frequently, least-developed countries. ${ }^{20}$ Formally, as an intergovernmental organization, the WTO provides a dispute forum for members (in other words, state-to-state litigation). However, it is hard to deny that governmental interests can be entangled with corporate interests. Some disputes at the WTO are even referenced by their corporate nicknames. In one prominent example involving governmental subsidies to the air industry, Brazil and Canada litigated over supports to their respective air industries, which became notorious as the Embraer-Bombardier dispute. ${ }^{21}$ Similarly, the EC-Biotech case revealed Monsanto's interest in the outcome because Monsanto's market access to genetically modified corn in the European market was in jeopardy. ${ }^{22}$ In addition, it has been argued that the Banana War dispute, involving the United States as complainant and the European Community (EC) as defendant, has been backed by Chiquita, Dole, and Del Monte. The United States brought the dispute to the WTO despite the fact that it does not export any bananas to the European market; however, U.S.

20. For a statistical analysis, see Kara Leitner \& Simon Lester, WTO Dispute Settlement from 1995 to 2007: A Statistical Analysis, 11 J. INT'L. ECON. L. 179, 181-82 (2008).

21. These disputes took place from 1996 to 2003. For the respective reports, see Index of Dispute Issues, http://www.wto.org/english/tratop_e/dispu_e/dispu_subjects_index_e.htm\#aircraft (last visited Oct. 5, 2008). Similarly, the United States is currently challenging subsidies paid to Europe's Airbus, and Europe is disputing subsidies paid to U.S. manufacturer Boeing. The United States and the EC began consultations in 2004. A panel was established, but a final report has not yet been circulated.

22. This dispute was fully monitored by the media and the public. Besides the controversy itself, the confidential interim rulings of the panel were leaked and caused further reactions. The final report is more than one thousand pages long. See Panel Report, European Communities-Measures Affecting the Approval and Marketing of Biotech Products, WT/DS291, WT/DS292, WT/DS293 (Sept. 29, 2006). 
multinational corporations supported the dispute because they export to the European market from their Latin American production platforms. ${ }^{23}$

Finally, as Thomas Cottier explains, the traditional GATT modus operandi (negotiation of tariff concessions) has been in transformation. In a process that started in the Kennedy era, the international trade regime has faced myriad NTBs, including technical standards, sanitary and phytosanitary standards, and intellectual property issues. ${ }^{24}$ While government and large industries customarily discuss tariff barriers, NTBs involve a large number of stakeholders (such as standardization organizations, consumers, NGOs, and civil society in general) concerned with ethical consumption, development of standards, food safety, and other such issues.

At this point, you might be ready to put down the anchor and stop the vessel. To review the basic ideas that have been developed thus far, recall that the WTO is an intergovernmental organization. The WTO regulates the conduct of states. Disputes can be initiated by the formal solicitation of states and involve a mix of governmental and corporate interests. Moreover, with the enlargement of the multilateral trade regime and the proliferation of NTBs, the number of stakeholders involved in WTO issues has increased, along with the oversight of the organization's activities. The sea of the WTO is deeper than one may have imagined.

\section{Corporate Social Responsibility}

\section{A. Overview}

The second leg of this journey explores the sea of CSR. Do not drift away as you navigate these new waters, and do not look ahead to the strait connecting them with those of the WTO. The third part of your journey will provide the necessary link.

Generally speaking, CSR embodies numerous initiatives aimed at tackling negative aspects associated with the operation of corporations, such as exploitative social practices including forced labor and environmental degradation. ${ }^{25}$ These

23. Int'l Centre for Trade and Sustainable Dev., EU Banana Regime Condemned Again, BRIDGES, Feb. 2008, available at http://ictsd.net/i/news/bridges/3133/.

24. Thomas Cottier, Preparing for Structural Reform in the WTO, 10 J. INT'L ECON. L. 497, 500-05 (2007). The WTO Secretariat has prepared a format for member notifications of NTBs. See Negotiating Group on Mkt. Access, Table of Contents of the Inventory of Non-Tariff Measures, TN/MA/S/5/Rev.1 (Nov. 28, 2003).

25. For a definition, see Jennifer A. Zerk, Multinationals and Corporate Social ResponSIBILITY: LIMITATIONS AND OPPORTUNITIES IN INTERNATIONAL LAW 32 (2006) (noting the difficulties in defining CSR, but proposing that CSR "refers to the notion that each business enterprise, as a member of the society, has a responsibility to operate ethically and in accordance with its legal obli- 
practices often occur within operations in developing countries. Though the downside of multinational corporations' operations can also be addressed by state regulation, CSR is understood as belonging to a broader system of governance in which non-governmental actors, voluntary codes of behavior and certification of social and environmental standards come into play.

A number of factors have contributed to the fast-growing pace of CSR initiatives. These factors include governments tackling corporate-related problems; NGOs' participation and involvement; consumer movements; and, in some cases, the role of business leaders committed to CSR principles. Moreover, one needs to understand that the sea of CSR has many different facets. First, CSR is addressed under a number of rubrics, including transnational regulatory systems, non-state market driven (NSMD) governance systems, civil regulation, and private authority, to name a few. ${ }^{26}$ Second, CSR manifests itself through different initiatives. For instance, at the level of sponsorship, there are CSR initiatives sponsored by nonprofit organizations, business entities, global chains of production, international organizations, and religious groups. Hybrid structures also exist in which more than one type of entity is involved in an initiative and perhaps include some level of governmental participation. Moreover, as already highlighted, CSR initiatives can be implemented through different mechanisms such as voluntary codes, reporting systems, and labeling and certification procedures.

\section{B. CSR Initiatives}

It is not the objective of this article to present a comprehensive discussion of CSR initiatives, but rather it is simply to introduce them and highlight some of their features. The following well-known CSR initiatives serve as useful illustrations: the International Social and Environmental Accreditation and Labeling Alliance (ISEAL), the United Nations Global Compact (UNGC), and the Organization for Economic Cooperation and Development (OECD) Guidelines. ${ }^{27}$

ISEAL is an umbrella for organizations including the Fairtrade Labeling Organization International (FLO), the Forest Stewardship Council (FSC), the

gation and to strive to minimise any adverse effects of its operations and activities on the environment, society and human health").

26. Bernstein \& Hannah, supra note 1 , at 2 . The authors adopt non-state market driven (NSMD) governance in their own work on the basis that it is widely cited and has generated the most detailed and distinct categorization of CSR mechanisms. Id.

27. Organization for Economic Cooperation and Development [OECD], The OECD Guidelines for Multinational Enterprises (2000), available at http://www.oecd.org/dataoecd/56/36/1922428.pdf. 
International Organic Accreditation Service (IOAS), and five others. These eight organizations, under the coordination of ISEAL, aim to set social and environmental standards in sectors ranging from forestry and agriculture to fisheries, manufacturing, and textiles. ${ }^{28}$ ISEAL has been described as one of the "most relevant examples of NSMD systems" that offers a "Code of Good Practice for Setting Social and Environmental Standards" to its members. ${ }^{29}$ Illustrating the many tentacles of ISEAL, the FLO in turn convenes with another twenty-three organizations dealing with labeling initiatives. The FLO itself covers labeling of sixteen types of products, including bananas, cocoa, coffee, cotton, and flowers. ${ }^{30}$

The UNGC corresponds to a CSR initiative created by the United Nations and was first pursued by former U.N. Secretary-General Kofi Annan in 1999. The UNGC describes itself as "the world's largest, global corporate citizenship initiative" and states that it provides a framework for businesses that are committed to aligning their operations and strategies with ten universally accepted principles in the areas of human rights, labor, the environment, and anti-corruption, thus mainstreaming these principles in business activities around the world. ${ }^{31}$

Finally, in another example, the OECD revised and adopted new guidelines for the operation of multinational enterprises in $2000 . .^{32}$ The OECD Guidelines establish voluntary recommendations relating to human rights, responsible supply chain management, labor relations, environmental concerns, consumer protection, and bribery issues. The OECD Guidelines is a good example of the types of initiatives that this article refers to as hybrid mechanisms because they are supported by governments through National Contact Points (NCPs). These points are responsible for implementing and promoting the Guidelines and usually constitute governmental offices that "gathers ... information on national experiences

28. See ISEAL Alliance, ISEAL Code of Good Practice for Setting Social and Environmental Standards, http://www.isealalliance.org/index.cfm? fuseaction = Page.viewPage\& pageId = 841 \&gra ndparentID $=500$ \& parent $I D=502$ (last visited Nov. 5, 2008).

29. Bernstein \& Hannah, supra note 1.

30. FLO International, Fairtrade Products, http://www.fairtrade.net/producers.html (last visited Oct. 4, 2008).

31. See United Nations Global Compact, What is the UN Global Compact, http://www.ungloba lcompact.org/AboutTheGC/index.html (last visited Oct. 4, 2008), for an overall description of the UNGC.

32. The OECD is an international organization established in 1961 and currently comprises a membership of thirty countries committed to democracy and the market economy from around the world. For more information on the organization, see Organization for Economic Cooperation and Development, http://www.oecd.org/ (last visited Oct. 4, 2008). 
with the Guidelines, handles enquiries, discusses matters related to the Guidelines and assists in solving problems that may arise in this connection." ${ }^{33}$

CSR is not a sea of quiet waters; criticisms of these initiatives do exist. In 2006, The Economist published an article criticizing the economic basis of fair trade schemes, such as the Fairtrade label governed by the FLO. The British magazine, despite acknowledging that "such food [labeled fair] allows shoppers to express their political opinions, from concern for the environment to support for poor farmers, ${ }^{\prime 34}$ pointed out that fair trade is in some respects deleterious. By encouraging a greater supply of coffee, fair trade contributes to a further decrease in the world price of coffee. Thus, maintaining artificially high prices may leave the majority of coffee producers worse off. ${ }^{35}$

The UNGC has also been the target of criticism. ${ }^{36}$ One commentator, despite acknowledging that the initiative "paved the way for the United Nation's engagement with key non-state actors to tackle pressing challenges of the twenty-first century," stated that the UNGC principles are general and vague. ${ }^{37}$ Ensuring that corporations joining the initiative will fulfill their responsibilities both in letter and spirit will result in better quality control. ${ }^{38}$

Finally, regarding the OECD Guidelines, in June 2008 John Ruggie, the U.N. Special Representative of the Secretary General in charge of the relation of human rights and transnational corporations and other business enterprises, submitted his final report to the Human Rights Council. In the report, Ruggie recommended that the OECD Guidelines be revised because "their current human rights provisions not only lack specificity, but in key respects have fallen behind the voluntary standards of many companies and business organizations." ${ }^{39}$

33. Organization for Economic Cooperation and Development, National Contact Points for the OECD Guidelines for Multinational Enterprises, http://www.oecd.org/document/60/0,3343,en_ 2649_34889_1933116_1_1_1_1,00.html (last visited Oct. 3, 2008).

34. Voting with Your trolley, ECONOMIST, Dec. 9, 2006, at 81.

35. For arguments from FLO responding to The Economist, see Response to The Economist (Dec. 15, 2008), http://p20126.typo3server.info/single_view.html? \&L = 1\&cHash = 0276a7fe6e\&tx_ ttnews[backPid] $=104 \& \mathrm{tx} \_$ttnews[tt_news] $=11$.

36. Surya Deva, Global Compact: A Critique of the U.N.'s "Public-Private" Partnership for Promoting Corporate Citizenship, 34 SYR ACUSE J. INT'L L. \& COM. 107, 111 (2006); see also Evaristus Oshionebo, The U.N. Global Compact and Accountability of Transnational Corporations: Separating Myth From Realities, 19 FLA. J. INT'L L. 1, 37 (2007) (arguing that the initiative offers only "moral suasion" to the business community).

37. Deva, supra note 36 , at $149-50$.

38. Id.

39. Spec. Rep. of the Secretary-General on the Issue of Human Rights and Transnational Corps. and Other Bus. Enterprises, Protect, Respect and Remedy: A Framework for Business and Human 
In sum, CSR concerns non-governmental actors and their struggle to develop "regulation" for multinational corporations. CSR initiatives and tasks have proliferated in number and content (voluntary codes; labeling; certification processes; reporting of abuses; and, though not explored here, technical assistance). They also vary with respect to their sponsorship and as to the level of government involvement.

\section{Confluence of Seas}

\section{A. Quasi-Confluence, a Quasi-WTO, and a Quasi-CSR}

Thus far, we have navigated two separate seas. It is noteworthy that it was possible to find a route on each without acknowledging the other. One commentator has suggested the reasons for their separation: "[S]ome might ask why governments or international institutions such as the WTO should play any role in promoting CSR in global markets ... [since] market forces (consumers, producers and other stakeholders) are clearly demanding ethical behavior [from corporations]." ${ }^{.40}$ The reality, nonetheless, is that these seas are connected by troubled waters, and what seems to be a contemporary discussion actually has older roots. This observation leads us to our first encounter with the sea creatures.

Recall that before the GATT 1947 was implemented, the creation of the ITO was proposed. Although infrequently noted in the literature, Chapter 2 of the proposed ITO dealt with employment and economic activity. Specifically, Article 7 of Chapter 2 centered on "fair labour standards." Arguably, had that provision been adopted, the multilateral trade system might have had already from the time of its creation a closer connection with CSR, at least with respect to minimum labor standards. ${ }^{41}$

More broadly, it is relevant to keep in mind why this first potential confluence of seas was not realized, as it supports the perception of the GATT 1947 (and now the WTO) as an intergovernmental organization polarized by different groups among

Rights, II 46, U.N. Doc. A/HRC/8/5 (Apr. 7, 2008), available at http://www.reports-and-materials. org/Ruggie-report-7-Apr-2008.pdf. For a summary of the report, see generally Christiana Ochoa, The 2008 Ruggie Report: A Framework for Business and Human Rights, ASIL INSIGHT, June 18, 2008, http://www.asil.org/search.cfm? displayPage $=1059$.

40. Aaronson, supra note 1 , at 633.

41. It is hard to speculate, though, how such a mechanism could have evolved or been implemented within the system. It is possible even to deny that such a connection would have resulted. One could merely argue that such clause would only provide a link to other international conventions concerning labor, and that the GATT 1947 would still have had nothing to do with the regulation of corporations. 
its membership—developed and developing countries. An argument historically advanced by developed countries is that introducing a social clause (the other label for minimum labor standards in a trade regime) ensures that successful market competition is not achieved through systematic violation of workers' rights. On the other hand, developing countries feared that labor standards would simply serve to justify protectionist measures. For developing countries, moreover, labor standards constituted a valid comparative advantage, and in a country expected to grow economically, labor conditions would gradually improve. Such irreconcilable positions have produced enduring consequences. Despite many attempts, a social clause has never been introduced during the almost fifty years of the GATT 1947 or WTO. ${ }^{42}$

While this article suggests a quasi-confluence of the multilateral trade regime and labor standards, the intersections of the regime with environmental issues have recently occupied the global agenda. The 1990s have been identified as a key period in the debate, which commenced at the United Nations Conference on Environment and Development (UNCED) in Rio de Janeiro and continued with the growth of environmental NGOs. ${ }^{43}$

In the 1990s, the Tuna cases emerged. ${ }^{44}$ Mexico brought the case against the United States, challenging the Marine Mammal Protection Act (MMPA) that regulated, inter alia, the harvesting of tuna. The MMPA required the U.S. government to ban the importation of commercial fish or products caught with commercial fishing technology that results in the incidental killing of or infliction of serious injury on ocean mammals in excess of U.S. standards. Mexico contested the validity of the MMPA under the GATT 1947 rules. The panel, after interpreting the GATT 1947, ruled in favor of Mexico. Because of the outcome of the case, environmentalists depicted the system as "GATTzilla," though the allusion, and the scope of the conflict between trade and environmental protection, was "greatly exaggerated."45

As the fisherman encounters GATTzilla, tuna, and dolphins, two additional

42. See Robert Howse et AL., The World Trade Organization and Labour Rights: Man Bites Dog, in Social Issues, Globalization and International. Institutions 157, 174-97 (Virginia A. Leary \& Daniel Warner eds., 2006) (describing the historical context of trade and social rights from 1919 through the first five years of the WTO).

43. Jagdish Bhagwati, Trade and the Environment: The False Conflict?, in TradE AND THE ENVIronment: Law, Economics, and Policy 159, 159-60 (Durwood Zaelke et al. eds., 1993).

44. Two related cases include: Panel Report, United States-Restrictions on Imports of Tuna, WT/DS21/R-39S/155 (Sept. 3, 1991) (unadopted) [hereinafter Tuna I] and Panel Report, United State-Restrictions on Imports of Tuna, WT/DS29/R (June 16, 1994) (unadopted) [hereinafter Tuna $I I]$. To be "unadopted" means that the report did not bind the litigants of the dispute.

45. Bhagwati, supra note 43, at 161. For more on the GATTzilla allusion and even a picture of it, see Daniel C. Esty, Greening the GatT: Trade, Environment, and the Future 34-35 (1994). 
observations are relevant. First, developing and developed countries disagree about trade and environmental issues, with the latter fearing that environmental standards could serve protectionist purposes. Second, the Tuna cases popularized the nomenclature and literature of process and production methods (PPM), which are still pivot points regarding current CSR issues. ${ }^{46}$

The first confluence of the seas does not entirely address what this article has identified as CSR (voluntary codes of conduct and certification of standards). This explains the "quasi" adjectives used in the section title. The first confluence is largely about the tension between government regulation, labor and environmental standards, and the goal of trade liberalization. One could simply acknowledge this confluence as a chapter of the trade and non-trade debate. Still, even if, strictly speaking, CSR was not directly involved, the first confluence paves the way and provides context for the analysis of the second confluence. Now, the debate is broadened to its full extent, taking into account the multitude of CSR initiatives.

\section{B. Second Confluence of Seas}

This article earlier introduced CSR initiatives, including the ISEAL certification, the OECD Guidelines, and the UNGC. Having distinguished between purely private initiatives (ISEAL) and hybrid sponsorships (OECD Guidelines and the UNGC), it is time to explore the dynamic phenomenon by which CSR initiatives intersect with the WTO.

CSR initiatives have recently begun to permeate governmental action. Susan Aaronson argues that this process of intersection began in industrialized countries in 2001. She notes, for instance, that the EC issued a green paper on promoting a European framework for CSR; Canada hosted the third summit of the Americas in Quebec City and inserted language promoting CSR into the Summit's Plan of Action; the United States placed exhortative language encouraging CSR in the Singapore, Chile, and Central America Free Trade Agreements; and the EC, following the U.S. approach, began to introduce CSR language into its cooperation agreements. ${ }^{47}$ Aaronson also identifies specific national initiatives, such as Dutch leadership on CSR; Proudly South Africa, a partnership among

46. See infra Part IV.B on PPMs. For references to this discussion, see Tuna I, II $3.17-18,3.21$, 4.2 and Tuna II, II 4.4-6; 4.44.

47. Aaronson, supra note 1, at 637-38; see also Susan A. Aaronson \& Jamie M. Zimmerman, Trade Imbalance: The Struggle to Weigh Human Rights Concerns in Trade Policymaking (2008) (describing studies of policymaking initiatives with respect to human rights in trade from South Africa, Brazil, the European Union, and the United States). 
the South African government, organized laborers, businesses, and the community, which certifies companies that meet certain fair labor, employment, and environmental standards; the Costa Rican government partnership in the tourism sector certifying eco-friendly hotels; the Colombian government's partnership with the United States funding environmentally responsible production of goods such as cocoa, rubber, forest products, and coffee; and a Belgian law promoting socially accountable production by introducing a voluntary social label and a certification process through the Ministry of Economic Affairs. ${ }^{48}$

These examples illustrate that CSR initiatives adopted by governments through legislation can become subsumed within the apparatus of the WTO, including mechanisms used to resolve trade disputes. This is not to contend that the initiatives evolved for the purpose of becoming embedded in trade measures; such a claim would require a detailed analysis of each initiative separately. However, the vessel can enter obscure waters where the distinctions between voluntary and mandatory, and governmental and non-governmental, are not so clear. This point clearly illustrates the impact of the WTO on CSR issues.

There are many other examples that also make this point. A European Commission report describes CSR elements in EU trade instruments. ${ }^{49}$ For instance, two directives enacted in 2004 deal with social and environmental criteria that can be used in public procurements. Further, some EC members have linked the allocation of export credits or guarantees to adherence to social or environmental criteria. In a more alarming tone, in the context of Chinese industry, Ethical Behavior magazine stated that the "rumour that the SA8000 labour accreditation was going to become a standard set by importers of Chinese goods has caused panic in business circles ... [and] manufacturers [were] complaining that the West was using SA8000 as a "big stick." ${ }^{50}$ In another example, a piece of German legislation requiring all federal

48. Aaronson, supra note 1 , at $639-41$.

49. European Commission, Directorate-General for Trade, Corporate Social Responsibility and Trade Policy - Implementing CSR Practices and the OECD Guidelines for Multinational Enterprises in Developing Countries (June 7, 2004); see also Andrew Clapham \& Joanna B. Martignoni, "Are We There Yet?" In Search of a Coherent EU Strategy on Labour Rights and External Trade, in SociaL Issues, Globalization and INTERnational Institutions, supra note 42, at 233, 239, 269, 272 (identifying choices open to the EU in considering labor rights issues and trade, from regulations with binding and direct applicability within the national law of EU members to support for social labeling initiatives or CSR).

50. China and the Corporate Responsibility "Trade Barrier," ETHICAL CORP.: EC NEwsDESK (Ethical Corporation), Sept. 16,2004, http://www.ethicalcorp.com/content.asp? ContentID=2779. 
government agencies to buy timber from sustainably managed forests has been identified as a way to integrate environmental standards into government policies. ${ }^{51}$

Aside from the political and legal question of whether any of these initiatives would ever generate a trade dispute and be held a protectionist measure under a covered agreement, they have prompted stakeholders to consider the possible tests that CSR initiatives might be subject to in accordance with trade law. The pertinent questions are first, can one member establish standards for other members' production of a product and impose a trade barrier if the standards are not followed; second, who has the authority to set international standards in social and environmental areas; and third, can one member adopt more stringent standards than those included in the multilateral framework.

It is time to weigh anchor one more time. In arriving at an answer to the questions just posed, we will encounter shrimp, sardines, and salmon. Some observations about WTO disputes will provide the necessary coordinates.

\section{Loading the Deck: A Little Bit of Shrimp, Sardines and Salmon}

\section{A. Remarks about WTO Disputes}

Shrimp, ${ }^{52}$ Sardines, ${ }^{53}$ and Salmon ${ }^{54}$ are three of the more than 350 cases that have been initiated under the dispute proceedings of the WTO. ${ }^{55}$ Reports of the disputes contain long analyses of the arguments raised by the complainants and defendant members. Academics have written numerous articles analyzing and criticizing panels and appellate body reports. This part of the journey is simply a brief effort to summarize key dispute issues and relate them to CSR issues.

To begin with, many provisions of the covered agreements contain ambiguities and are unclear. This should not come as a surprise. If ambiguity occurs fre-

51. Tom Rotherham, Standards and Labeling, in Trade and Environment: A Resource Book 179, 179-80 (Adil Najam et al. eds., 2007), http://www.trade-environment.org/page/southernagenda/ RB_2-16.htm.

52. Appellate Body Report, United States-Import Prohibition of Certain Shrimp and Shrimp Products, WT/DS58/AB/R (Oct. 12, 1998) (adopted Nov. 6, 1998) [hereinafter Shrimp].

53. Appellate Body Report, European Communities-Trade Description of Sardines, WT/DS231/ AB/R (Sept. 26, 2002) (adopted Oct. 23, 2002) [hereinafter Sardines].

54. Appellate Body Report, Australia-Measures Affecting Importation of Salmon, WT/DS18/ AB/R (June 12, 1998) (adopted Nov. 6, 1998) [hereinafter Salmon].

55. A case may involve multiple complainants as parties. Though the DSU uses the term "complainant party," "defendant member" is not mentioned. I use it here as a shorthand for "member against whom the complaint has been brought." Third party members also frequently join disputes. 
quently in situations when two people negotiate a private contract, one can imagine the vast potential for ambiguity in international instruments, where multiple parties draft texts in languages that may not be their official language. Add to this the difficulty of addressing new issues and you will have an idea of what happens during the drafting of international agreements.

Dispures among members have, to some extent, clarified the meaning of the text and also offered guidance for future interpretation. Importantly, the DSU, which contains the procedural rules governing the dispute resolution process, contains no rule of stare decisis; however, previous rulings of the panels and the $\mathrm{AB}$ are taken into account in subsequent proceedings, which leads to some level of predictability. ${ }^{56}$ The reliance on previous cases is an important component of the multilateral trade system.

Because the covered agreements are treaties under international law, panels and the $A B$ use the rules of interpretation of international law contained in the Vienna Convention on the Law of Treaties (VCLT) in resolving disputes. ${ }^{57}$ In short, the VCLT stipulates that a treaty shall be interpreted in good faith, in accordance with the ordinary meaning of its terms in their context (including pre-

56. Interestingly, at the WTO, there has been a recent meeting of the DSB to discuss the application of the principle of stare decisis in WTO disputes. See Dispute Settlement Body, Minutes of Meeting, WT/DSB/M/250 (July 1, 2008). One commentator has summarized the minutes:

- The U.S. thinks prior AB (and panel) reports should create "legitimate expections[sic]" but not be binding.

- The EC seems to approve of $\mathrm{AB}$ reports being something close to binding.

- Japan, Hong Kong, India and Mexico seem to agree with the AB's concerns about panels departing from $\mathrm{AB}$ jurisprudence.

- Chile expresses some concerns about the AB's statements on this issue; and Colombia seems to be worried that the $\mathrm{AB}$ has overreached a bit.

Simon Lester, The Role of Precedent: What WTO Members Think (Part 2), International Economic Law and Policy Blog, http://worldtradelaw.typepad.com/ielpblog/2008/09/the-role-of-pre.html (Sept. 1, 2008, 6:23 EST).

57. Nowadays, the VCLT is considered, without major objections by the international community, to express the customary rules of treaty interpretation. As Jackson comments,

although this convention does not technically apply in some situations, and would not technically apply in a controversy involving a nation - such as the United States - that has not yet ratified [it. The VCLT] ... is considered by many nations, including the United States, to codify generally accepted rules of customary international law, and thus is a definitive text describing those rules.

JACKSON, supra note 5, at 120-21. 
ambles and annexes), and in light of its object and purpose. ${ }^{58}$ In applying those rules, the $\mathrm{AB}$ relies heavily on the text of the relevant agreement. ${ }^{59}$ Referencing the ordinary, dictionary definition of a word is a common practice.

Disputes are also affected by the scope of the agreements. Different disciplines are covered by distinct treaties. Clauses in those agreements define the scope of their application. The GATT 1994 covers trade in goods. It has been the cornerstone of the multilateral trade regime since it replaced the GATT 1947. The TBT also applies to goods, including industrial and agricultural products, ${ }^{60}$ and on matters of mandatory technical regulations and voluntary standards. ${ }^{61}$ The TBT does not apply to government procurement and SPS measures. ${ }^{62}$ The GPA, as previously mentioned, has a limited scope regarding its membership (plurilateral agreement). It applies to any law, regulation, procedure, or practice regarding procurement.

Finally, the SPS covers four main categories of measures to be taken within the member's territory. In sum, it covers the protection of animal or plant life from pests and disease; the protection of human or animal life from risks arising from additives, contaminants, and toxins generally found in food and drink; the protection of human life from zoonoses; and the protection of a country from establishment of pests. ${ }^{63}$

Though one might assume that a bright line distinguishes the scope of the agreements, in actuality, overlaps likely occur between them. As Marceau and Trachtman

58. Vienna Convention on the Law of Treaties arts. 31, 32, May 23, 1969, 1155 U.N.T.S. 331.

59. Lennard, supra note 2, at 87; see also Donald McRae, Treaty Interpretation and the Development of International Trade by the WTO Appellate Body, in THE WTO AT TEN: THE CONTRIBUTION OF THE Dispute SetTlement System 360, 364 (Giorgio Sacerdoti et al. eds., 2006) (criticizing the inconsistency of dictionary use by the $\mathrm{AB}$ and observing that "anyone who has pleaded a case knows that you can usually find a dictionary meaning to support the meaning that your client prefers").

60. Agreement on Technical Barriers to Trade, art. 1.3, Apr. 15, 1994, 33 I.L.M. 1125 [hereinafter TBT].

61. In accordance with the definition found in the TBT, compliance with standards is voluntary while technical regulations are mandatory. See id. annex 1, art. 1 ("Technical regulation: Document which lays down product characteristics or their related processes and production methods, including the applicable administrative provisions, with which compliance is mandatory. It may also include or deal exclusively with terminology, symbols, packaging, marking or labelling [sic] requirements as they apply to a product, process or production method."); see also id. annex 1, art. 2 ("Document approved by a recognized body, that provides, for common and repeated use, rules, guidelines or characteristics for products or related processes and production methods, with which compliance is not mandatory. It may also include or deal exclusively with terminology, symbols, packaging, marking or labelling [sic] requirements as they apply to a product, process or production method."). The TBT also covers conformity assessment procedures, as defined in Article 3 of Annex 1.

62. Id. arts. 1.4-1.5.

63. Agreement on the Application of Sanitary and Phytosanitary Measures, annex A, art. 1(a)-(d), Apr. 15, 1994, 1867 U.N.T.S. 493 [hereinafter SPS]. 
point out, "[T] he applicable WTO law is itself determined by the specific aspects of the measure challenged [by the complainant member], the nature of the disciplines imposed by each provision, and the relationship between these provisions." ${ }^{44}$

You are now prepared for the final leg of our journey.

\section{B. Shrimp (and Turtles) on the Boat: PR-PPMs and NPR-PPMs}

Shrimp is a landmark case found at the WTO dock. The issue in that case was whether the United States (the state regulating the importation of shrimp) could regulate the process by which shrimp were harvested outside U.S. waters (specifically in India, Malaysia, Pakistan, and Thailand). The United States alleged that harvesting shrimp in these Asian countries harmed turtles. This case is virtually a duplicate of the Tuna cases, except that it concerns turtles rather than tuna.

The case relates to CSR in its discussion of PPMs. But what are PPMs exactly? A fundamental distinction exists between "product-related" processes and production methods (PR-PPMs) and "non-product related" processes and production methods (NPR-PPMs). PR-PPMs refer to measures that prescribe processes and production methods that affect the characteristics of products; NPR-PPMs, on the other hand, entail measures that prescribe processes and production methods that do not, or at least only negligibly, affect the characteristics of the products. ${ }^{65}$ For instance, while a measure prohibiting the use of certain antibiotics in shrimp farming would be a PR-PPM, a measure requiring that fishing vessels use turtle-friendly nets would be an NPR-PPM. ${ }^{66}$ In the first case (PRPPMs), the final product would be affected, because shrimp not treated with antibiotics are "antibiotic free," while shrimp treated with antibiotics can carry residues. In the second case (NPR-PPMs), regardless of whether the shrimp were harvested with turtle-friendly nets, the final product would be the same.

Historically, trade controversies have been about the validity (or invalidity) of NPR-PPMs (PR-PPMs are not very controversial). This is so because the GATT 1994 and other covered agreements impose the obligation to treat, "like products"

64. Marceau \& Trachtman, supra note 12, at 815 .

65. Peter Van den Bossche et al., Unilateral Measures Addressing Non-Trade Concerns, at xxxvii-xxxviii (2007), availableat http:/www.minbuza.nl/binaries/kamerbrieven-bijlagen/2007/09/ u0417dgisce-boek-wt.pdf; see also WALTER GoODE, Dictionary of POLICY TRADE TERMS 282 (2003). The acronym PPM is sometimes used loosely in the literature, most of the time, the controversies involving PPMs are about NPR-PPMs.

66. This is just a point to distinguish PR-PPMs from NPR-PPMs. I am not stating which covered agreement applies to the dispute. For instance, in the case of the prohibition of imported shrimp farmed with certain antibiotics, the SPS agreement, dealing with food safety, is likely the relevant one. 
equally ${ }^{67}$ If shrimp harvested with nets that harm turtles are considered "like" shrimp harvested with turtle-friendly nets, members would not be able to impose NPR-PPMs. In other words, discriminating among the processes by which shrimp are harvested would be improper. By analogy, in the labor context, if a product " $P$ " produced using child labor is to be considered "like" a product "P" produced with adult labor, members would not be able to impose NPR-PPMs and treat them differently. Amidst the many technicalities contained in the Shrimp decision, an accepted conclusion is that the GATT 1994 does not prohibit NPR-PPMs.

As many CSR initiatives (for example, certification of social and environmental standards), involve the differentiation of products by reference to social and environmental criteria, CSR stakeholders have been watching for further developments of trade disputes on NPR-PPMs. They fear that if the WTO prohibits NPR-PPMs, the legality of related CSR initiatives would be called into question. Moreover, while Shrimp offers some guidance on NPR-PPMs in the context of the GATT 1994, a question remains as to whether the same understanding should apply to the TBT agreement. Technically speaking, the standards found in CSR initiatives meet the definition of the TBT, which covers not only mandatory regulations but also voluntary ones. ${ }^{68}$

\section{Fishing for Sardines: Who Defines Standards?}

Your second fishing exercise involves sardines. The Sardines case provides insights about the meaning of "relevant international standards." In contrast to the Shrimp case, this case involves the direct interpretation of the TBT agreement.

In the Sardines case, Peru challenged a European regulation providing that only one species of sardine caught in European waters could be sold in the European market under the name "sardines." ${ }^{\circ 9}$ Peru alleged that the EC should have used the Codex Standard 94, developed by the Codex Commission. ${ }^{70}$ If that standard were used, it would have been permissible for Peru to export sardines and to sell them in the European market under the name "sardines."

67. TBT, supra note 60 , art. 2.

68. In the TBT definitions of both technical regulation and standards, "related processes and production methods" are initially mentioned, but by the end of the definitions, the language "product, process or production method" is used. Id. at annex 1.1 .

69. The measure at issue is Council Regulation 2136/89, 1989 O.J. (L 212) 22 (EC), which entered into force January l, 1990.

70. The international standard is Codex Standard 94-1981, Rev.1-1995, which covers preserved sardines or sardine-type products prepared from twenty-one fish species. 
This case raises an interesting question relevant to CSR: who sets the applicable standards? In addressing this question, the following two major concerns arise: standardization institutions want to be among the recognized bodies that set the standards; and members are increasingly worried that social and environmental standards are essentially demands made by developed countries, with no active engagement of developing countries in determining the mechanisms by which these standards are set.

The interpretation of "relevant international standards" came into play in the case itself. Since the TBT provides that "[w]here technical regulations [such as the EC Regulation] are required and relevant international standards exist or their completion is imminent, members shall use them, or the relevant parts of them, as a basis for their technical regulations." Furthermore, a standard is defined in the TBT as a "document approved by a recognized body,"? and an explanatory note provides that "[s]tandards prepared by the international standardization community are based on consensus. This Agreement also covers documents that are not based on consensus." ${ }^{\prime 3}$

Considering all of these elements together leads to the conclusion that the $\mathrm{AB}$ did the following: it did not clarify the meaning of "recognized body" because the EC did not contest that the Codex Commission was an international standardization body $;{ }^{74}$ it did uphold the panel decision finding "that even if not adopted by consensus, an international standard can constitute a relevant international standard"; $;{ }^{75}$ and it did corroborate the panel's decision that for a standard to be relevant, it has to "to bear upon, relate to, or be pertinent to" the measure at stake.

In sum, the Sardines case does not go very far in establishing further rules about standards. The case leaves open the issue of who is a "recognized body" that may set standards and indicates only that consensus is not essential for a particular international standard to constitute a "relevant international standard."

\section{Some Room for Salmon: Stringent Levels of Protection}

Finally, make room on your deck for a load of salmon. The Salmon case provides additional insight about standardization issues. Unlike the Shrimp and Sardines cases, however, this case involves the interpretation of the SPS agreement. In

71. TBT, supra note 60 , art. 2.4 (emphasis added).

72. Id. annex 1, art. 2 (emphasis added).

73. Id.

74. Sardines, supra note 53 , at 221.

75. Id. at 222-27.

76. Id. at 229-33. 
this case, Canada claimed that Australia's ban on importing fresh, chilled, or frozen salmon violated WTO rules. The extent to which members could apply stringent measures of protection concerning SPS measures involving food safety became a central issue. Overall, the SPS requires members to adopt SPS measures based on scientific principles. ${ }^{77}$ The relationship with science is thus a foundational basis of the SPS, though provisional measures are possible in cases where relevant scientific evidence is insufficient. ${ }^{78}$

The Salmon case relates somewhat obliquely to $\mathrm{CSR}^{79}$ but does reveal additional concerns regarding the debate on standards. First, in order to promote the broadest harmonization of such measures as possible, the SPS encouraged members to base their SPS measures on international standards, ${ }^{80}$ although it did leave space for members to establish more stringent measures. Another aspect of the agreement is that, unlike the TBT, the SPS enumerates the relevant international organizations for the purposes of identifying international standards. ${ }^{81}$

Thus, while CSR initiatives such as social and environmental standards are likely to bear a close relationship to the interpretation of the GATT 1994 and the TBT, the SPS reinforces an overall framework of trade incentives for members to use international standards as the basis of their trade measures.

\section{Where Will the Beacons Turn their Lights?}

After sailing around potential issues in the covered agreements and WTO jurisprudence relating to issues of CSR (NPR-PPMs and international relevant standards being two of them), let us steer the vessel to recent proposals on future linkages. This is the last leg of the journey.

77. SPS, supra note 63 , art. 2.2 .

78. Id. art. 5.7 .

79. The relationship between the SPS and voluntary standards developed by the food industry is a topic of discussion among members and the Secretariat of the WTO. Generally, food industry standards are used in transactions between large buyers and small suppliers, which have to follow a certain standard often related to food safety. Suppliers who do not comply with these standards are, in practice, out of business. In March 2007, the Committee on Sanitary and Phytosanitary Standards discussed this issue. Int'l Centre for Trade and Sustainable Dev't, WTO Body Debates Public, Private Food Safety Standards, Bridges TRADE BioRes, Mar. 16, 2007, available at hitp://ictsd.net/i/news/biores/9324/.

80. SPS, supra note 62 , art. 3.1 .

81. Id. annex A, art. 3. The recognized bodies are: the Codex Alimentarius Commission, for food safety; the International Office of Epizootics, for animal health and zoonoses; and the International Plant Protection Convention, for plant health. The SPS also provides that other relevant international organizations may be identified by the SPS Committee for matters not covered by the above organizations, though so far none has been identified. 
As previously noted, at least three recent papers have addressed these issues. Bernstein and Hannah focus on NSMD. Building on the concept of policy space, they propose that the WTO should leave transnational regulatory space for social and environmental standards rather than trying to create additional rules on what to accept. ${ }^{82}$ They note that NSMD is gaining legitimacy and support in the society and trade arena and argue that the WTO should simply carve out "negative" space rather than take "positive action" that will require active policy making and high-level political consensus. They favor, in their own words, a non-interventionist approach, on the basis that more overt action would be unlikely to succeed. ${ }^{83}$ More specifically, they recommend that the WTO avoid establishing rules on NPR-PPMs or privileging any standardization bodies. ${ }^{84}$ Their proposal appropriately recognizes the political sensitivity of those issues in an accurate manner. However, a non-interventionist approach may ignore the fact that private standards are normally demanded by developed countries. In this way, at least keeping the relevant WTO committees as a place to debate the issue does not seem to be improper, as commentators from Brazil have suggested. ${ }^{85}$

Aaronson approaches CSR and the WTO by describing many initiatives that national policymakers are using to link CSR to trade policies and agreements (including beyond the WTO context). She identifies six areas of contention where WTO rules may undermine responsible corporate behavior, including government procurement and social- and eco-labeling ${ }^{86}$ Noting that many members are struggling to find a way to encourage both trade and CSR and that CSR is neither under the WTO mandate nor subject to current negotiation, she suggests that the WTO establish a research agenda, possibly in concert with other international organizations. I have two observations about her proposal. First, using the word "undermine" to assess the impact of the WTO on CSR is a bit strong. Most CSR initiatives are simply outside the scope of the WTO. Members' opposition is intended to keep the WTO out of the CSR business rather than to prompt a trade

82. Bernstein \& Hannah, supra note 1 , at 4.

83. Id. at 32 .

84. Id. at 33 .

85. Rodrigo Lima \& Welber Barral, Barreiras não-Tarifárias ao Comércio: o Papel Regulatório da OMC, Controverrsias e Novas Restrições [NTBs: The Regulatory Role of the WTO, Controversies and New Barriers], 93 Revista Brasileira de Comercio Exterior [Brazilian J. of Foreign Trade] 73,83 (2008).

86. Aaronson acknowledges six areas: TRIPS and access to affordable medicines; TRIPS and traditional knowledge; export processing zones and labor rights; business in conflicting areas; procurement rules and CSR; and social- and eco-labeling. Aaronson, supra note 1, at 644-51. 
decision on CSR. (It is true, nonetheless, that as CSR initiatives permeate governmental action a hypothetical case may eventually be subject to trade rules scrutiny.) Second, though a formal agenda of CSR under the WTO Secretariat has not thus far been established, some cross-fertilization has already occurred. In February 2007, for instance, the International Labour Organization and the WTO Secretariat issued Trade and Employment: Challenges for Policy Research. ${ }^{87}$ In its third public forum, the WTO will address concerns about the organization's mandate. ${ }^{88}$ The WTO Secretariat also employs staff that actively publishes articles related to trade and non-trade concerns. ${ }^{89}$

Finally, Caroline Foster's point of departure is democracy, more specifically, the role of public opinion in the interpretation of the SPS. In her view, members should be able to defend SPS measures on the basis that their population does not want to bear a given risk. ${ }^{90}$ She advances her claim that disproportionate measures could possibly be the result of genuinely held views, and that the SPS must accommodate such positions. Additionally, Foster suggests that in practice, "risk assessments" required by the SPS would eventually involve a close examination of the internal consultation processes carried out with those populations. ${ }^{91}$ What may sound paradoxical in her proposal is that the point of departure (the democratic deficit and illegitimacy of the WTO) is accompanied by a solution that may worsen the problem. Involving panels and the $A B$ in closer analysis of internal

87. Marion Jansen \& Eddy Lee, Trade and Employment: Challenges for Policy Research (2007), available at http://www.wto.org/english/res_e/booksp_e/ilo_e.pdf. I am referring here to a cross-institutional cooperation example rather than a trade-CSR research agenda itself.

88. The 2007 forum had a specific discussion on global governance, including social standards. See WTO Public Forum 2007, http://www.wto.org/english/forums_e/public_forum2007_e/ topics_e.htm (last visited Oct. 4, 2008); see also WTO Secretariat, WTO Public Forum 2006: What WTO for the XXIst Century?, Sept. 25-26, 2006, at 71, http://www.wto.org/english/res_e/ booksp_e/public_forum06_e.pdf.

89. See, e.g., Robert D. Anderson \& Hannu Wager, Human Rights, Development, and the WTO: The Cases of Intellectual Property and Competition Policy, 9 J. INT'L ECON. L. 707 (2006); Gabrielle Marceau, A Call for Coherence in International Law, 33 J. WORLD TRADE 87 (1999); Gabrielle Marceau, WTO Dispute Settlement and Human Rights, 13 EUR. J. INT'L L. 753 (2002).

90. Foster, supra note 1, at 432.

91. Id. at 452. She concludes that such an approach is consistent with international human rights law by surveying relevant human rights law. Id. at 453-55. In the context of the role of public opinion on the formation of customary international law, see Christiana Ochoa, The Individual and Customary International Law, 48 VA. J. INT. L. 119, 182-84 (2007) (discussing, among other things, two examples of projects that illustrate the viability and potential utility of large scale polling for the purpose of assessing beliefs, expectations, and practices, the Eurobarometer and Afrobarometer). 
consultation processes carried out by members' populations may backfire even more with respect to legitimacy.

Overall, these recent analyses suggest more or less interventionist approaches for the WTO in future matters of CSR, and this article is aimed at providing context for that discussion.

\section{Conclusion}

The waters of the WTO and CSR seas are distinct. The WTO is an intergovernmental organization establishing members' rights and obligations regarding multilateral trade; CSR, though not uniquely defined, entails, for example, voluntary codes of conduct and certification initiatives tackling corporate behavior in areas of social and environmental standards. However, as our fisherman's journey proves, a strait may exist between those waters. This is demonstrated perhaps most obviously by the fact that whenever a member adopts a CSR initiative under its law, it may be challenged as a trade measure, bringing interpretation of the covered agreements, particularly the GATT 1994, the TBT, the SPS, and the GPA, into play. Aside from this dynamic, the WTO touches CSR issues indirectly. Furthermore, the WTO jurisprudence does not advance interpretations of NPR-PPMs or relevant international standards that could impinge on CSR initiatives. 

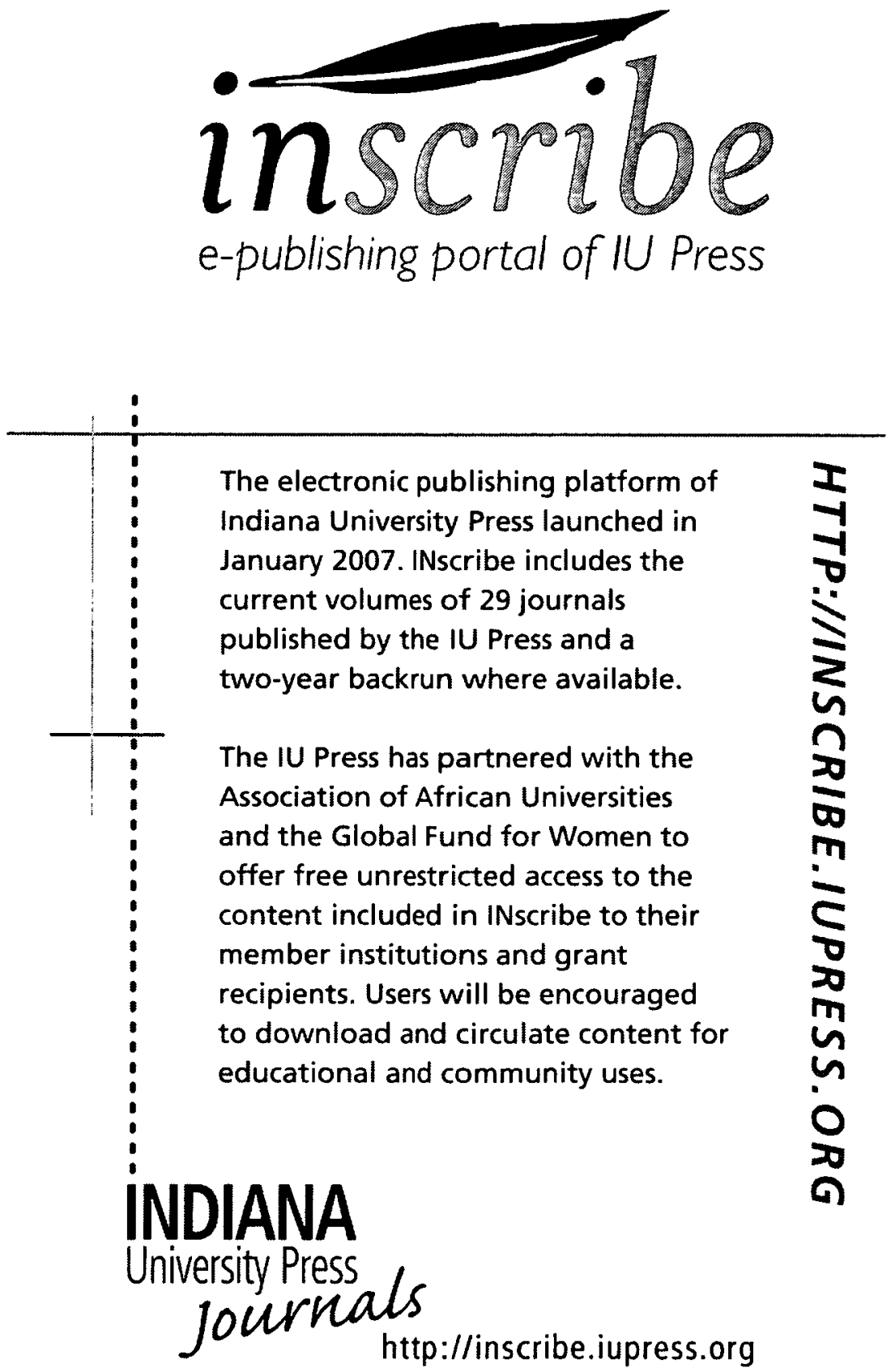